\title{
Canadians' Perception of Confucius Institutes: Culture Experience or Political Propaganda?
}

\author{
Ting $\mathrm{Wu}$ \\ Faculty of Politics and Law of Zhaoqing University \\ Zhaoqing, Guangdong, China \\ prettywuting@126.com
}

\begin{abstract}
The purpose of this paper is to elaborate how Canadians think about China's Confucius Institutes. The article argues that Chinese leaders describe the Confucius Institutes around the world as the tool of spreading appreciation for Chinese culture and language. However, the majority of officials and the masses of Canada are insisted that Confucius Institutes are closely linked to the Chinese Communist Party which designed to convey Communist ideology. Moreover, Canadians believe that as educational institutions, the Confucius Institutes are not compatible with the principle of independence from political interference. Lacking of knowledge fosters the misunderstanding of Canada and China. Therefore, there should be more engagement between the two nations.
\end{abstract}

Keywords-Perception of Canadians; Confucius Institutes; Propaganda Workers

\section{INTRODUCTION}

With the enhancement of China's comprehensive power, China is asserting increasing influence over international affairs. The international community is paying increasing attention to China's role and goals in international relations much more. At the same time, the theory of the "China threat" in western world is being revived. As the "old friend" of China, Canada shows a complicated psychology to the rising of China. Canadians are widely seeing China as a threat, which brings about the continuous comments of "Chinese culture immersion”. For China's Confucius institutes, Canada regards them as the tools of policy propaganda and brainwashing. This idea hinders the development of cultural relations between the two countries. China-Canada relations have remained a tepid state, which is not only due to the mismatch of state structure; the social cognition also plays a vital role. This paper tries to illustrate the cognitive obstacles of the China-Canada relations on the basis of their interaction in culture field.

\section{CONFucius Institutes IN CANADA}

\section{A. Confucius institutes of China}

Confucius institute is an important form of cultural exchanges with foreign countries. Over the past several years, Confucius Institutes have sprouted in many locations in Asia, Africa, North America, Europe and Oceania since the first Confucius institute was established in Seoul in 2004. By the end of 2016, a total of 512 Confucius Institutes and 1073 Confucius Classrooms had been set up in 140 countries or regions [1].
The Confucius Institutes have altogether 46000 full-time and part-time native Chinese and indigenous teachers, with 1.55 million students instructed face to face and 597000 students registered online. In 2016, 41000 a variety of cultural activities have been held, attracting more than 13 million participants [2].

At present, Confucius Institutes have developed online international Chinese-language teaching, adopting the Realtime Interactive Teaching Method to provide a platform to Chinese language and culture learners. At the end of 2016, the number of registered online users reached 8.9 million, an increase of nearly 1 million compared with the number over the previous year. About 414000 students have registered for the online teaching program, and with 183000 new users, the number of registered users has totaled 597000 [3].

The objective of Confucius institutes given by the Hanban is that they are non-profit education institutions co-established by China and foreign countries, aiming to provide scope for people all over the world to learn about Chinese language and culture [4]. In addition, the Confucius institutes have become a platform for cultural exchanges between China and the world as well as a bridge reinforcing friendship and cooperation between China and the rest of the world.

\section{B. Confucius institutes in Canada}

China established the first Confucius institute in Canada in 2005, which was jointly developed by the British Columbia Institute of Technology (Canada) and Southwest University (China). As China's economy and exchanges with Canada have seen rapid growth, there has also been a sharp increase in the demands for Chinese learning. So far there are 12 Confucius Institutes and 35 Confucius Classrooms in Canada, accounting for only $2.3 \%$ and 3.3 of all the institutes and classrooms in the global world. Canada is not the promising destination for the Confucius institutes' development, ascribed to that Canada has never been put at the top of China's diplomatic agenda.

On the perspective of cooperation model, Confucius Institutes in Canada is implementing the school system cooperated by colleges and local education authorities from the two countries. This model is able to better meet the requirements of the universities of Canada and provide the services including teaching, offering teaching materials and consulting and so forth. Based on its own characteristics and the actual situation of the colleges, the Confucius institutes in Canada have shaped some unique traits. For example, the 
Mandarin course in Vancouver's Confucius Institute puts more attention to the exchange of economy and culture, teaching Chinese-related communication skills and specializing in Chinese language courses for business people. The Confucius Institute in Quebec set up two branch institutes at Dorothy College and University of Sherbrooke, the former teaches in English and provides Chinese short-term training courses, while the latter teaches in French and offers postgraduate courses in Chinese literature, law and medicine.

TABLE I. CONFUCIUS INSTITUTES IN CANADA

\begin{tabular}{|c|c|c|c|c|}
\hline $\begin{array}{l}\text { Confucius } \\
\text { Institute }\end{array}$ & $\begin{array}{c}\text { Start } \\
\text { Running } \\
\text { Time }\end{array}$ & City & $\begin{array}{c}\text { Foreign } \\
\text { Institution }\end{array}$ & $\begin{array}{c}\text { Chinese } \\
\text { Institution }\end{array}$ \\
\hline $\begin{array}{l}\text { Confucius } \\
\text { Institute at } \\
\text { University } \\
\text { of Regina }\end{array}$ & $2011 / 11 / 04$ & Regina & $\begin{array}{l}\text { University } \\
\text { of Regina }\end{array}$ & $\begin{array}{c}\text { Hunan } \\
\text { University }\end{array}$ \\
\hline $\begin{array}{c}\text { Confucius } \\
\text { Institute at } \\
\text { BCIT }\end{array}$ & $2006 / 02 / 07$ & Vancouver & $\begin{array}{c}\text { British } \\
\text { Columbia } \\
\text { Institute of } \\
\text { Technology }\end{array}$ & $\begin{array}{l}\text { Southwest } \\
\text { University }\end{array}$ \\
\hline $\begin{array}{l}\text { Confucius } \\
\text { Institute in } \\
\text { Coquitlam }\end{array}$ & $2008 / 04 / 29$ & Coquitlam & $\begin{array}{c}\text { Coquitlam } \\
\text { School } \\
\text { District }\end{array}$ & $\begin{array}{c}\text { South } \\
\text { China } \\
\text { Normal } \\
\text { University }\end{array}$ \\
\hline $\begin{array}{l}\text { Confucius } \\
\text { Institute in } \\
\text { Waterloo }\end{array}$ & $2007 / 05 / 03$ & Waterloo & $\begin{array}{l}\text { University } \\
\text { of Waterloo }\end{array}$ & $\begin{array}{c}\text { Shanghai } \\
\text { internationa } \\
1 \text { studies } \\
\text { University }\end{array}$ \\
\hline $\begin{array}{c}\text { Confucius } \\
\text { Institute in } \\
\text { Quebec }\end{array}$ & $2007 / 10 / 08$ & Montreal & $\begin{array}{l}\text { Dawson } \\
\text { College }\end{array}$ & $\begin{array}{c}\text { Beijing } \\
\text { Normal } \\
\text { University }\end{array}$ \\
\hline $\begin{array}{l}\text { Confucius } \\
\text { Institute in } \\
\text { New } \\
\text { Brunswick }\end{array}$ & $2007 / 07 / 15$ & Moncton & $\begin{array}{c}\text { Department } \\
\text { of } \\
\text { Education } \\
\text { in New } \\
\text { Brunswick } \\
\end{array}$ & $\begin{array}{c}\text { Shandong } \\
\text { Provincial } \\
\text { Education } \\
\text { Department }\end{array}$ \\
\hline $\begin{array}{l}\text { Confucius } \\
\text { Institute in } \\
\text { Edmonton }\end{array}$ & $2008 / 05 / 04$ & Edmonton & $\begin{array}{l}\text { Edmonton } \\
\text { Public } \\
\text { Schools }\end{array}$ & $\begin{array}{c}\text { Shandong } \\
\text { Provincial } \\
\text { Education } \\
\text { Department }\end{array}$ \\
\hline $\begin{array}{c}\text { Confucius } \\
\text { Institute at } \\
\text { Brock } \\
\text { University }\end{array}$ & $2010 / 05 / 05$ & $\begin{array}{c}\text { St. } \\
\text { Catharines }\end{array}$ & $\begin{array}{c}\text { Brock } \\
\text { University }\end{array}$ & $\begin{array}{l}\text { Minjiang } \\
\text { University }\end{array}$ \\
\hline $\begin{array}{l}\text { Confucius } \\
\text { Institute at } \\
\text { Carleton } \\
\text { University }\end{array}$ & $2012 / 04 / 19$ & Ottawa & $\begin{array}{l}\text { Carleton } \\
\text { University }\end{array}$ & $\begin{array}{c}\text { Central } \\
\text { China } \\
\text { Normal } \\
\text { University }\end{array}$ \\
\hline $\begin{array}{l}\text { Confucius } \\
\text { Institute at } \\
\text { Saint } \\
\text { Mary's } \\
\text { University } \\
\end{array}$ & $2010 / 10 / 20$ & Halifax & $\begin{array}{c}\text { Saint Mary's } \\
\text { University }\end{array}$ & $\begin{array}{c}\text { Amoy } \\
\text { University }\end{array}$ \\
\hline $\begin{array}{c}\text { Confucius } \\
\text { Institute at } \\
\text { Seneca } \\
\text { College }\end{array}$ & $2011 / 11 / 24$ & Toronto & $\begin{array}{l}\text { Seneca } \\
\text { College }\end{array}$ & $\begin{array}{l}\text { Northeast } \\
\text { Normal } \\
\text { University }\end{array}$ \\
\hline $\begin{array}{c}\text { Confucius } \\
\text { Institute at } \\
\text { University } \\
\text { of } \\
\text { Saskatche } \\
\text { wan }\end{array}$ & $2012 / 06 / 18$ & Saskatoon & $\begin{array}{l}\text { University } \\
\text { of } \\
\text { Saskatchew } \\
\text { an }\end{array}$ & $\begin{array}{c}\text { Beijing } \\
\text { Institute of } \\
\text { Technology }\end{array}$ \\
\hline
\end{tabular}

\section{CANAdians' PeRCEPTION OF CONFucius Institutes}

The emergence of Confucius Institute and the craze for Chinese language serves as a solid proof that "only a prosperous country can guarantee the well-being of its people and popularize its language". With the explosive mainland economy, the amount of Confucius Institutes in Canada increases gradually, leading to a growth of Chinese-related teachers. Thus, Canadians begin to concern more about China who is the rising oriental power. As for the attitude to Confucius Institute, sentiment in Canada is divided into two groups. The supporters believe that the Confucius Institutes plays a key role in teaching Chinese, spreading Chinese culture and building soft power. In the wake of the improvement of China's influence, understanding Chinese and Chinese culture is conducive to the exchange between China and Canada. While that is not how the majority of Canadians saw it, voice within the mainstream of the Canadian society is to "watch out Confucius Institutes".

\section{A. Official attitude}

In 2013, the Canadian Security Intelligence Service (CSIS) held a conference in collaboration with National Defense Canada, and release a report about the security threat of an influential China. The report claims that Confucius Institutes being closely linked to the Chinese Party-state are funded and controlled by the Chinese Ministry of Education. It is bound to have a primarily political agenda. Therefore, Confucius Institute is a "propaganda worker" outputting the ideological orthodoxy of Theory of Socialism with Chinese Characteristics, as well as a machine of cultural infiltration and brain washing.

The report further points out that Confucius Institutes carried of political mission is not compatible with the principle of independence from political interference that is important for independent academic activity to flourish. This can be seen in three aspects:

In the first place, the Hanban is affiliated with the Chinese Ministry of Education, an organization that works according to the Higher Education Law that is designed to uphold the ideological orthodoxy of "Marxism-Leninism, Mao Zedong Thought and Deng Xiaoping Theory" [5]. The Hanban is even empowered to invoke punitive consequences on any person or party who engages in "any activity conducted under the name of the Confucius Institutes without permission or authorization from the Confucius Institute Headquarters" [6].

In the second place, teachers of Confucius Institutes are selective to spread the prejudicial and undemocratic idea of Chinese government. To be considered for a teaching and learning qualification, as the website of Hanban stated, an individual must have no record of participation in Falun Gong and other illegal organizations and no criminal record, which is in contradiction with the unethical and illegal culture of university in the free world.

In the third place, Confucius Institutes do not allow critical discussion of topics that the Chinese government deems sensitive, such as the status of Tibet and Taiwan or the 1989 Tiananmen massacre. This is collided with the spirit of university to promote "freedom of thought and expression". 
According to the report, "the Confucius Institute, to me, functions like the closed circulation television and has the potential to scare away my critical thinking by constantly reminding me: we are watching you and behave yourself' [7].

\section{B. Public attitude}

Canadians are conservative about the Confucius Institutes as well. The higher support for engagement with the European Union and Australia can be explained, in part, by Canadians' relative comfort with partners viewed as familiar and politically like-minded. The 2014 national opinion poll of Asia-Pacific Foundation shows that Canadians are afraid of the political differences with Asian countries. Canadians who see their security interests best served by strengthening ties to traditional allies are distinctly less willing to engage with Asian countries than are Canadians who express support for building relations with a broader group of countries. Likewise, Canadians are reluctant to accept the cultural impact on Canada of Asian countries. As the survey indicated that $60 \%$ of respondents expressed a strong concern for the impact of other cultures on their lives, and $61 \%$ express much greater opposition to provincial government who is plan to add more Asian language courses in public schools. However, there is a particularly sharp distinction when it comes to respondents being familiar with the Asia (16\%) who are more willing to accept and respect Asian culture. More than three-fifths (63\%) support promote more Asian language and culture courses in education system of Canada, compared to only $39 \%$ among the Canadians who had never contacted with Asians before [8].

The reports of Canadian mainstream media are exactly the same with views above. Under the rendering of media, the Confucius Institute has become a political tool, limited academic freedom, cultivated spy and outputted the culture of the Chinese Communist Party. There appears a trend that cultural and educational activities are gradually politicized in Canada, and this is confirmed by the termination of the Confucius Institute in Toronto at the end of October 2014.

The Toronto District School Board (TDSB) is the largest public school boards in Canada, overseeing public schools with 232,000 students. In April 2014, the TDSB signed the agreement with the Hanban to build the fifth Confucius Institute in Ontario, whose initial purpose is using the Confucius Institute, a non-profit to promote Chinese culture and connections around the world, to offer mostly after-school programming to teach Mandarin, Chinese art and culture to elementary students.

However, on May 22, hundreds of people protested against the agreement outside the door of TDSB at the opening of the Institute for worrying about that the TDSB officially severed its ties to a Confucius Institute subsidized and controlled by the government of China and took the education polity which brainwashes. In October, the TDSB voted to end a planned partnership with China's government-funded Confucius Institutes in public schools.

Many people commented on this event. Pamela Gough, a member of the TDSB pointed that we've absorbed some value that was not consistent with our true nature and we were living according to those false values and were creating internal conflict within ourselves. Most of the evidence showed that the Confucius Institutes were controlled by the Chinese Communist Party which restricted the critical discussion of many topics. Charles Burton, a professor at Brock University, further said that Beijing is certain to take note of the highprofile cancellation of the Confucius Institute in Toronto schools. "Canada's reputation in China as being hostile to Chinese foreign policy goals will be enhanced by the fact of Canada's largest school board causing the Chinese side to lose face by openly and publicly denouncing the idea of a Confucius Institute"[9].

The cancellation of the accord is the latest setback for China and its effort to project soft power by using the governmentfunded Confucius Institutes to improve its image around the world. Recently, the University of Chicago and Pennsylvania State University in the United States also shuttered their institutes amid concerns about the impingement of academic freedoms. David Mulroney, a former ambassador to China, said the controversy over the institutes demonstrates the need to make such agreements public and ensure that foreign countries comply with Canada's traditions of academic freedom. "We're seeing really the end of the free ride that Confucius Institutes have had, particularly in North America," Mr. Mulroney said in an interview. "I don't think you're going to see as many new Confucius Institutes in the wake of the high-profile crisis to date." [10]

China's Foreign Ministry spokeswoman Honglei has rejected criticism of the Institutes, saying that the Confucius institute is aiming to help foreigners learn more about Chinese language and cultures, plays a key role in promoting the mutual understanding between China and the world, and follows the trend of letting the world know China and China going the global [11].

\section{SUMMARY}

China and Canada have differences and divergences on the creation of Confucius Institutes. China stressed that the Confucius Institute project is an attempt to increase Chinese language learning, an appreciation of Chinese culture, a broader soft power projection in which China is attempting to win hearts and minds [12]. It's not a political project, but a cultural plan carrying the idea of "harmony in diversity" which can be the ideological foundation of solving many complex problems in the world. While Canada is more concerned about the way Confucius Institute works and its relationship with the Chinese government, which is very easy to distort the function of the Confucius Institutes. As a consequence, there is hard to say whether the establishment of Confucius Institutes is helping China win friends around the world. China promotes Chinese language learning throughout the world by doing exactly what she wants to do. It is worth to note that if you can't figure out the relationship of language promotion and foreign policy, it is subject to achieve no good effects. China has successfully established Confucius Institutes in an impressive array of countries and regions, but the actual influence and benefits China derives from this project are currently limited to shaping preferences in language learning and attitudes towards China [13]. 


\section{ACKNOWLEDGMENT}

This research was financially supported by the Doctoral Scientific Research Start-up Project of Zhaoqing University.

\section{REFERENCES}

[1] Confucius Institute Headquarters (Hanban), Confucius Institutes Annual Development Report, 2016, pp.14

[2] Ibid., pp.14.

[3] Ibid., pp.33.

[4] Hanban of China, http://english.hanban.org/node_10971.htm, accessed to 13 June 2017.

[5] Canadian Security Intelligence Service, Confucius Institutes: Distinguishing the Political from the Culture, The Security Dimensions of An Influence China, Government of Canada, 2013, pp. 123.

[6] Ibid., pp.124.

[7] Ibid. , pp. 125 .
[8] Asia Pacific Foundation, National Opinion Poll: Canadian Views on Asia Investment, Vancouver: Asia Pacific Foundation of Canada, 2014.

[9] Andrea Hopkins, Toronto schools set to reject Confucius deal, likely irritating China, http://www.dailymail.co.uk/wires/reuters/article2813263/Toronto-schools-set-reject-Confucius-deal-likely-irritatingChina.html, accessed to 15 June 2017.

[10] The Globe and Mail, TDSB votes to officially cut ties with Confucius Institute, https://www.theglobeandmail.com/news/toronto/torontoschool-board-votes-to-sever-ties-to-confuciusinstitute/article21376636/, accessed to 12 June 2017.

[11] The China News, Chinese Foreign Ministry's Response to the termination of the Confucius institute of Toronto education bureau, http://www.chinanews.com/gn/2014/10-30/6734766.shtml,accessed to 10 June 2017. (in Chinese)

[12] James F. Paradise ,China and international harmony: The role of Confucius Institutes in bolstering Beijing's soft power, Asian Survey, Vol.49,No.4,2009.

[13] Jeffrey Gil, China' s Confucius Institute Project: Language and Soft Power in World Politics, The Global Studies Journal,Vol.2, No.1, 2009 